\title{
Dancing to the End of Humanity: Environmental Catastrophe in Earthquakes in London
}

\author{
Zümre Gizem YILMAZ KARAHAN*
}

\begin{abstract}
Human beings frequently exhibit destructive behaviours toward the physical environments in most of their institutions, including art. Within this context, some performance arts display the abject situation as a result of the bizarre encounters with the feared and disgusted other. This encounter consecutively determines the relational payoff of human beings. Such display also preserves the so-called distinction between human and Nature as nonhuman is presented as a piece of art separated from the self. Moreover, the exhibition of the Other as a cultural product unwittingly underlines that human beings reveal Nature as the Other prompted for the Cultural gaze. This categorisation feeds on any nonchalance of human beings towards a potential environmental catastrophe created by the very categorisation between Nature and Culture. Within this framework, this study will focus on the nonchalance of humanity towards an unavoidable environmental catastrophe they created, which creates an anthropocentric dilemma. To exemplify this dilemma, this study will make use of examples from Mike Barlett's play entitled Earthquakes in London (2010).
\end{abstract}

Keywords: ecophobia, NatureCulture, contemporary British theatre, Mike Barlett, Earthquakes in London

\footnotetext{
* Dr. Öğr. Üyesi., Ankara Sosyal Bilimler Üniversitesi, İngiliz Dili ve Edebiyatı Bölümü, Ankara, Türkiye. Elmek: zumregizem.yilmaz@asbu.edu.tr https://orcid.org/0000-0003-3148-2447
} 


\section{İnsanlığın Sonuna Dans: Earthquakes in London Oyununda Çevre Felaketi}

\section{$\ddot{\mathrm{O} z}$}

İnsanlar çoğu zaman sanat dâhil çoğu kurumlarında çevreye karşı yok edici bir tutum sergilerler. Bu bağlamda, bazı performans sanatları korkulan ve nefret edilen ötekiyle tuhaf karşılaşmalar neticesinde ortaya çıkan ürkütücü durumları ortaya koyar. Bu karşılaşma da insanların bu bağlantıda hesaplaşmasını belirler. Aynı zamanda, bu tip sergilemelerle insan olmayan, insan özünden ayrı olarak bir sanat eseri statüsünde değerlendirildiğinden insan ve doğa arasındaki oluşturulmuş fark devam ettirilir. Ayrıca, Ötekinin kültürel bir ürün gibi sergilenmesi farkında olmadan, insanın Doğayı Kültür tarafından bakılacak Öteki olarak sınıflandırdığını da gösterir. Bu sınıflandırma insanların, yine Doğa ve Kültür arasında oluşturulmuş bu kategori neticesinde olması beklenen muhtemel çevresel felaketlere karşı duyduğu umursamazlıkla beslenir. Bu bağlamda, bu çalışma insanların kendilerinin yarattığı - ki bu da insan merkezli bakış açısının ikilemidir - önlenemez çevresel felaketlere karşı umursamazlığı üzerine odaklanacaktır. Bu ikilemi örneklendirmek içinse Mike Barlett'in Londra'da Depremler (Earthquakes in London - 2010) başlıklı oyunundan örnekler kullanacaktır.

Keywords: ekofobi, DoğaKültür, çağdaş İngiliz tiyatrosu, Mike Barlett, Earthquakes in London 
We live in frightening times. Finding a way forward in unknowability is scary. (Simon C. Estok, Ecophobia Hypothesis, 2018: 85)

ROBERT. Hold your breath. The planet can sustain about one billion people. We currently have six billion. (Mike Barlett, Earthquakes in London, 2010: 96)

The Human Subject might become the other, the object, or the abject at any point of an encounter, and that is why the Subject fears and hates the other without any solid reason. To describe this situation, Timothy Morton uses the phrase "strange stranger" enthused by Derrida's notion of the arrivant. He argues that "[o]ur encounter with other beings - and with our being as other - is strange strangeness" (2010: 275). He further contends how the other is actually the self, stating that "[s]trange strangers are uncanny in the precise Freudian sense that they are familiar and strange simultaneously. Indeed, their familiarity is strange, and their strangeness is familiar" (2010: 277). Granting the materiality and animality of human beings, Morton thus points to human and nonhuman entanglements. He further explicates the entanglements of human beings with nonhuman beings noting that " $[\mathrm{w}] \mathrm{e}$ share their DNA, their cell structure, subroutines in the software of their brains" (2010: 277). Attending to Morton's views, humans are bound to permeable and porous rules of the physical environment. This is what frightens people and causes ecophobia which Irish Ralph defines as "a catch-all term for aversion to and avoidance of the nonhuman other" (Ralph 2019: 401). Human beings tend to separate themselves from nonhuman nature to deny their materiality, hence rejecting that they are tied to porous existences that easily slip between nature and culture and so are "natureculture" things and beings. This rejection inevitably creates a dichotomy between nature and culture, articulating the superiority of mind over body. In performance arts, this clash exhibits how humans keep distance from both the nonhuman world and their nonhuman sides by seeing them as something separate. However, self-identity is an illusion as hu- 
man and nonhuman beings are self and other at the same time as a result of their material links. This is the gist argument of Timothy Morton's "strange stranger" and Simon Estok's ecophobia, both of which point to the fact that futile anthropocentric endeavours to form an identity as the ultimate agent obscure the borderline between nature and culture which denominates the former as the source of ill-omen.

Drawing attention to this constant discursive conflict between Nature and Culture, Friedrich Schiller states that "sense and reason, passive and active faculties, are not separated in their activities, still less do they stand in conflict with one another" (1985: 193). Schiller continues his discussion as follows:

Once man has passed into the state of civilization and art has laid her hand upon him, that sensuous harmony in him is withdrawn, and he can now express himself only as a moral unity, i.e., as striving after unity. The correspondence between his feeling and thought which in his first condition actually took place, exists now only ideally. (1985: 194)

Paul Alpers elaborates on Schiller's argument underlining that "[n]ature, which once was simply the world in which man found himself and acted, is now seen to be separate from him, and presents itself as the ideal of harmonious existence which he seeks to achieve" (1996: 29). In this relation, human beings have separated themselves from natural and material happenings, hence creating the cult of Civilisation and Culture superior to Nature. In the course of time, this has led to a separation between ontology and epistemology, which results in the distinction of mind over body - to be known as Cartesian Dualism. By doing so, human beings have culled themselves from the material formations of the world with an alleged role to shape these formations to their own end. In this regard, they have the ultimate control over the physical environment, and they can deflect material and environmental formations for their own use.

As a matter of fact, it results in a dichotomy when human beings exclude themselves from the ongoing intra-related formations, as if they exist outside the material world. Yet, the human does not separately observe the universe since he/ she is already inside it, and he/she is himself/herself constantly changing both materially and discursively. Karen Barad, in her own term "intra-action," underscores that relationships, as a result of which cultural and material meanings are 
produced, are on-going endless processes both among the bodies - be they human or nonhuman - and within each body itself. Another term by Barad, onto-epistemology, strengthens intra-active relationships in terms of compounding body and mind, which, in return, shatters the dichotomy between ontology and epistemology. Karen Barad enucleates these two terms as such:

Practices of knowing and being are not isolable; they are mutually implicated. We don't obtain knowledge by standing outside the world; we know because we are of the world. We are part of the world in its differential becoming. The separation of epistemology from ontology is a reverberation of a metaphysics that assumes an inherent difference between human and nonhuman, subject and object, mind and body, matter and discourse. Onto-epistem-ology - the study of practices of knowing in being - is probably a better way to think about the kind of understandings that we need to come to terms with how specific intra-actions matter. (2007: 185)

In the light of Barad's speculations, Nature is not an untouched harmonious sphere since there is an undeniable chaotic and disharmonious harmony in the physical environment. Supposing that nature is a pure and simple place serving humanity would only consolidate the basic dichotomy. As culture offers complex and more 'developed' relationships, this separation apparently paves the way for an anthropocentric point of view.

In this viewpoint, Nature is a bulk space awaiting a human being to master it. This perspective automatically puts a discrepancy between so-called inert and wild nature and civilised human culture, which adds another dimension in the professed supremacy of the Human Kingdom. This point of view has found its strength in the discourses of the Enlightenment in the Age of Reason $\left(18^{\text {th }}\right.$ century), especially through Descartes claiming that "since nature fills me with impulses of which reason disapproves, I did not think I should place too much trust in the teachings of nature" (1960: 158). At this point, it should be clarified that unlike Renaissance ideologies, acknowledging all nonhuman beings in the hierarchy of souls within the tripartite soul understanding, the Enlightenment ideology denies the existence of nonhuman beings within Cartesian understanding which degraded them to non-existent machines. As regards, Descartes prosecuted his discussions on setting the mind free at the expense of ignoring the body by predicating that the body is inferior to the mind. Problematising both ontology and 
epistemology, Descartes propounded a strict dichotomy between the body and the mind, that is matter (being) and discourse (knowing). This binary opposition inevitably caused strict and mechanistic boundaries between the thinking human being and the supposedly non-existent nonhuman, thus articulating the superiority of mind over body. This idea is surely parallel to the Renaissance Neo-Platonism which promotes the abdication of body and the exercise of reason to ascend to the ultimate good. Still, what is different in the Enlightenment is the configuration of existence which is denied to nonhuman beings since they allegedly lack rational faculty. Consequently, the body is belittled as all the organs functioning in the material body can operate in a machine, too, while the human mind is a unique creation, and this generates the distinctive position of human beings among nonhuman ones.

In the light of these discussions, such attitudes create varying and at times conflicting attitudes towards Nature, hence complicating ecophobia (irrational fear and hatred of Nature - developed by S. C. Estok) and biophilia (love of Nature - developed by E. O. Wilson) in many artworks. That is to say, when human beings lose control over nature, they tend to equate it with horror, terror, and disgust even though, paradoxically, when they celebrate nature, they generally tend to equate it with peace, harmony, and refuge. Art emancipates these feelings, and turns them into spectacles. This may be, however, related to "the awareness of one's vulnerability to an indifferent (and potentially hostile) environment" (Deyo 2019: 446). Interestingly though, this exclusion between two different life forms is emancipated only when nature accords to human rules, just as in the artworks demonstrating ecophobic feelings as a source of entertainment. They entertain us because this kind of aesthetic representation contributes to the development of human identity. In consequence, Nature becomes the other to firm Human identity as the Subject. This Subject is protected within discursive practices as if triumphing against a threat by an outside force which has somewhat escaped the human domain.

And it is Nature in most scenarios. Earthquakes in London by Mark Bartlett is one of those scenarios. The play portrays the life of three sisters abandoned by their father, Robert who is a climate scientist who predicts a probable environmental catastrophe. Robert underlines the polarization between Nature and 
Culture as the ultimate reason for this catastrophe noting that: "We were part of the system, a relationship, and we abused it. The world will be fine in the end, and it knows what it wants. It wants to get rid of us" (2010: 89). Robert not only puts the blame on the social wrongdoings for the environmental decline but also projects Nature as a vengeful formation taking revenge on humanity for their misuse. This kind of projection is the core of Simon C. Estok's ecophobia. Within this ideology, the physical environment corresponds to "a realm that is impure, unclean and disorderly to a murky, disavowed world that threatens propriety and identity" (Hughes 2009: 405). However, as Véronique Bragard underlines, "humans are defined by what they reject" (2013: 460). That is to say, the subjective identity is further settled with the definition of the other, which happens to be Nature in our case. Denying to be a part of Nature, human beings experience a dilemma in which they blame Nature for the environmental consequences of their own behaviours.

This dilemma promptly points to Estok's ecophobia. Coined by Simon C. Estok, ecophobia connotes the endeavor of human beings to take the physical environments and the basic units of nature under the control of their agency, which hints at the power relations bearing down an otherwise unruly nature. In his recent book entitled The Ecophobia Hypothesis (2018), Simon Estok fosters a limpid definition of ecophobia as follows:

It is a phobia that has largely derived from modernity's irrational fear of nature and hence has created an antagonism between humans and their environments. This antagonism, in which humans sometimes view nature as an opponent, can be expressed toward natural physical geographies (mountains, windswept plains), animals (snakes, spiders, bears), extreme meteorological events (Shakespearean tempests, hurricanes in New Orleans, typhoons), bodily processes and products (microbes, bodily odors, menstruation, defecation), and biotic land-, air-, and seascapes (every creeping thing that creepeth, every swarming thing that swarms, partings of - and beasts from - the sea). (2018:1)

The emphasis on the "irrational" in the definition of ecophobia points to the fact that ecophobia adheres its practices to the vindication and groundless demonstration of the frustrated human agency, which Estok relates to the control impulse of human beings. To put it somewhat differently, human beings try to take nature under their control so as to reinforce their privacy and subjective agency. 
This makes ecophobia "a yearning for control combined with either a general indifference or an outright contempt for the natural world and its inhabitants" (Estok 2018: 11). This contempt, we see in Earthquakes in London, leads to a complacence and even a celebration confronted with a potential environmental decline.

Estok's correlation indeed shows parallelism with Robin van Tine's term "gaeaphobia" which van Tine defines as "a form of insanity characterized by extreme destructive behavior towards the natural environment and a pathological denial of the effects of that destructive behavior" (1999: np). More occupied with psychological disorders, this term yet mirrors the spirit of the Anthropocene ${ }^{1:}$ "We are 'preoccupied with fantasies of unlimited success, power, and brilliance', believing that we can and will conquer all diseases, understand everything there is to understand about nature and the universe. ... We believe that we are 'unique' and expect to be recognized as superior by all other creature" (1999: np). From this perspective, both gaeaphobia and ecophobia capture the fear of losing private identities. Similar to gaeaphobia's framing phantasies of unique human beings in charge of everything, ecophobia encompasses a passionate love of human agency: "Agency is precious to humanity - so precious that the loss of it puts in peril not only our sense of exceptionalism but our very sense of human identity" (Estok 2018: 21-22). Therefore, the fear resulting from both of these theoretical concepts is to lose the privacy and superiority which took centuries for humans to settle down.

At this point, David Sobel's formulation of ecophobia is also noteworthy. Estok's ecophobia fundamentally differs from Sobel's ecophobia since Sobel identifies ecophobia as helplessness, anxiety, fear, and powerlessness especially on children in consequence of their alienation from the physical environment. As regards, Susan Jean Strife underscores that "[f]ocusing on ... distant and abstract issues may cause children to feel overwhelmed by environmental problems, perpetuating ecophobic feelings" (2012: 38). On the contrary, Estok defines ecophobia as motivation as a result of which human beings internalize such feelings. Put differently, while Sobel's ecophobia fosters a kind of fear as a result of environmental degradation, Estok's ecophobia highlights that ecophobia is the prime reason for recent environmental problems in the Anthropocene. Therefore, unlike 
Sobel, Estok questions the underlying causes of the ecological degradation. Furthermore, Estok does not hint at the outcome, but he rather underlines the process itself that promulgates the fear of being outside along with the notion that home is safe. Characters in Earthquakes in London suffer from such syndrome. They see outside nature and the physical environment as their enemies.

This safety idea is also reinforced by the technological artefacts such as Instagram filters, which provide users with an artificial and virtual area to enrich one's photography with fake nature filters. The reason of these filters is ecophobic since it promotes a dichotomy between inside and outside, and offers a safe version of the "outside" only filtered by human technology, hence adapting the unruly and wild nature to the cultural products. Within this framework, specific virtual applications present ecophobia as entertainment and turn the underlying feelings within the ecophobic psyche into the gaze submitting itself to the appreciation of the human eyes. That is the same reason why characters in the play dance and drink to their end. They indeed celebrate their death. Moreover, the old and wise narrator summarises how they turn such buoyant and indifferent:

\footnotetext{
It is said that in the old times, in the early years of the twenty-first century, mankind only thought of himself. The people would steal from the land and plunder the seas, they would kill the animals, tear out the minerals from the ground and poison the sky. And as the earth grew darker, the sun burnt brighter, and the sea began to rise, the people simply closed their eyes and drank, and danced, and attempted to ignore their certain destruction. (2010: 138)
}

So, this indifference stems from rigid categorisations of outside and inside, and human and nonhuman. People suffer from an awareness of their survival being tied to the ecological balance. Nevertheless, they still think they are more than Nature. Or they may desire the end of their ills and of their inaccurate and deformed fleshy existence. They want to disregard their natural side, and they celebrate the End of the current material and natural formations.

In the play, the eldest sister is a cabinet minister for the environment, and she is blackmailed to halt air traffic for the sake of environment by Tom who slept with Sarah's 19-year-old sister. He holds naked photos of her sister, and he is blackmailing her in order to stop air travel which has disastrous effects on his village in Africa: 
SARAH. [...] I assume you're going to tell me about the current and tangible effects of climate change on the agriculture, on the villages, your family.

TOM. You're aware of all that.

SARAH. That's sort of my job.

TOM. Then it's worse. You know what's going on and you allow runways and flight paths. You don't listen, we've raised petitions, spoken to our MPs, all you say is you 'appreciate our view', you 'encourage the debate' - but nothing happens. (2010: 52)

As for the middle sister, although she is pregnant, she gradually gets depressed because of the possibility of the polluted future for her child. She even contemplates suicide to avoid bringing her child into an apocalypic future. Within the framework of an environmental fear, the play dramatizes three sisters gradually understand that their father's pessimistic forecasts may be right in their ways. This realisation, however, is contrasted with people who are obviously dancing to their end, to their extinction.

From this viewpoint, nature is the source of ecophobic hatred and fear as it is what makes humans natural, too. As regards, Brian Deyo underscores that

while Estok maintains ecophobia is probably universal inasmuch as it is a symptom of human beings' feelings of insecurity with respect to the unpredictability of nature in the most general sense, he also suggests it may denote anxiety that what goes by the name of "Man" is insuperably tied to an animal body, to nature, to mortality, in addition to a realm of contingency over which it has limited control. And it is precisely this anxiety that may have been particularly unsettling throughout the course of settler histories. (2014: 91)

Therefore, facing the fact that we are that Nature othered in discursive practices is the gist of ecophobia. And human beings have an inherent loathing for their natural and bodily parts simply because these parts define them as nonhuman indicating materiality and mortality.

Ecophobia is the feeling that humans inherently feel at the moment of any close encounter with the other since this encounter reveals that "[ $t]$ he object of our fear ... becomes indistinguishable from ourselves, which is not to say that we become the world but rather that we become afraid of the shadows that we sense we are, scared as much by our inanimation as by the animation of the World" (Taylor 2012: 364-65). Within discursive practices, the subject is constructed at 
the expense of the death of its natural parts. However, realizing that humans are indispensably the other blows an irreversible hatred and fear towards that other. As a result, human beings try to take not only the physical environment but also themselves under their control in order to preserve the image of the cultural and civilized subject, hence vindicating Estok's statement that "[e]cophobia is all about frustrated agency" (2018: 10). Ecophobia adumbrates a breakdown in meaning when the distinction between the self and the other is no longer available. Consequently, the distinction set by the status quo shatters as well.

This deconstruction of the status quo, Deyo observes, might evoke "death anxieties triggered by our precognitive sense of the immensity, complexity, and power of nature" and "we [strongly] need to sustain faith in a cultural worldview" (2019: 451). In other words, the cultural denial of the human animality and materiality may evoke fear and hatred as it reminds us of our human limits as a natural consequence of the realization of "our precognitive sense of our creaturely embeddedness in natural processes" (2019: 451). Elise Mitchell states that this fear animates "the tension between the aversion and desire for control that characterize ecophobia" (2015: 102). This tension has its roots in the ontological categorizations of the living in ancient philosophy, put forward through a differentiation between bios and zoё. In Homo Sacer: Sovereign Power and Bare Life, Giorgio Agamben clarifies the basic distinction of these two spheres: "The Greeks had no single term to express what we mean by the word 'life.' They used two terms that, although traceable to a common etymological root, are semantically and morphologically distinct: zoē, which expressed the simple fact of living common to all living beings (animals, men, or gods), and bios, which indicated the form or way of living proper to an individual or a group" (1998: 1). Hence, the distinction between natural and cultural; outside and inside; and dangerous and safe becomes definite.

In a similar vein, artistic representations of the nonhuman as the distanced other achieves cultural mastery over the natural. Moreover, we see this in many apocalyptic scenarios both on stage and on screen. However, what we forget is that the loss of the other in consequence of an ecological decline also causes the loss of the subject who is defined by the other. Interestingly though, we still bring our end. We know we are destined to be destroyed because of our anthropocentric 
interference into the ecological balance of the world. Nevertheless, we still cannot stop. Remembering Estok's remarks that "[k]nowledge, in itself, is not enough. If it were, then there would be a lot less smokers in the world" (2018: 67), we tend to ignore blatantly approaching end: The End of the world: The End of humanity.

The play represents this indifference through Robert who claims that [p] eople say they want the truth - facts, and figures, but actually they want to be told it can be avoided, with minimum effort. When Neville Chamberlain came back from Hitler. He said he had a peace treaty, said he could trust his obviously evil man. Why did he believe it? Why did we believe it? Because we had to, or we'd be facing untold horrors. Always Steve, faith will come before truth. That's who we are. (2010: 95)

And this End is prevailing for all beings including themselves. Regardless of the visible consequences, they are celebrating their unawareness. More interestingly, they are celebrating their helplessness because they are indeed aware that it is irreversible now. It is just the End: "It's Weimar time, it's Cabaret, across the world. You feel it, we all do. We know there's nothing to be done, so we're dancing and drinking as fast as we can. The enemy is on its way, but it doesn't have guns and gas this time, it has wind and rain, storms and earthquakes" (Barlett 2010: 97). This quotation exemplifies both Estok's and Sobel's views on ecophobia. In this connection, people stop taking action to prevent environmental imbalance because they feel overwhelmed and crushed because of constant environmental problems. That is why they want to rejoice their limited times as the last human species of the terrestrial existence. On the other hand, this desperateness results in perceiving Nature as an opponent and enemy of the human civilization, hence furthering the gap between Nature and Culture. This creates more environmental problems since this gap triggers all social and environmental wrongdoings in the first place. This cycle cannot be broken unless people give up resigning to their so-called incapacity and failure in reversing their ills back.

At this point, a quotation from Margaret Atwood's story, "Time Capsule Found on the Dead Planet" seems apt:

You who have come here from some distant world, to this dry lakeshore and this cairn, and to this cylinder of brass, in which on the last day of all our recorded days I place our final words:

Pray for us, who once, too, thought we could fly. (2011: 193) 
We thought we could fly, we could ascend with the privilege we have gained from our Being status yet we must come to a realisation that we have limits, just like all the beings. We are exactly that strange stranger we are staging. We are facing the End of the World. We are facing ourselves.

It is the End.

Of Us.. 


\section{References}

Alpers, Paul (1996), What is Pastoral?, Chicago: The University of Chicago Press.

Agamben, Giorgio (1998), Homo Sacer: Sovereign Power and Bare Life, Redwood City, CA: Stanford University Press.

Atwood, Margaret (2011), "Time Capsule Found on the Dead Planet", M. Martin (ed.), in I'm with the Bears: Short Stories from a Damaged Planet (pp. 191-93), London: Verso.

Barad, Karen (2007), Meeting the Universe Halfway: Quantum Physics and the Entanglement of Matter and Meaning, Durham: Duke University Press.

Barlett, Mike (2010), Earthquakes in London, London: Bloomsbury Methuen Drama.

Bragard, Véronique (2013), "Introduction: Languages of Waste: Matter and Form in our Garbage”, ISLE: Interdisciplinary Studies in Literature and Environment, 20 (3), pp. 459-63.

Descartes (1960), Discourse on Method, London: The Whitefriars Press.

Deyo, Brian (2019), "Ecophobia, the Anthropocene, and the Denial of Death", ISLE: Interdisciplinary Studies in Literature and Environment, 26 (2), pp. 442-55.

Deyo, Brian (2014), "Rewriting History/Animality in J. M. Coetzee's Dusklands and Richard Flanagan's Wanting", Ariel: A Review of International English Literature, 44 (4), pp. 89-116.

Estok, Simon C. (2018), The Ecophobia Hypothesis, New York: Routledge.

Hughes, Bill (2009), "Wounded/Monstrous/Abject: A Critique of the Disabled Body in the Sociological Imaginary”, Disability \& Society, 24 (4), pp. 399-410.

Mitchell, Elise (2015), “There's No Place Like 'Home': Susanna Moodie, Shelter Writing, and Dwelling on the Earth", S. Oppermann (ed.), in New International Voices in Ecocriticism (pp. 101-16). Lanham: Lexington Books.

Morton, Timothy (2010), “Thinking Ecology: The Mesh, The Strange Stranger, and the Beautiful Soul”, Collapse, 6, pp. 265-93.

Ralph, Irish (2019), "Ecophobia and the Porcelain Porcine Species", ISLE: Interdisciplinary Studies in Literature and Environment, 26 (2), pp. 401-12.

Schiller, Frederich (1985), “On Naïve and Sentimental Poetry”, H. B. Nisbet (ed.), in German Aesthetic and Literary Criticism: Winckelmann, Lessing, Hamann, Herder, Schiller, Goethe (pp.177-232), Cambridge: Cambridge University Press.

Strife, Susan J. (2012), “Children's Environmental Concerns: Expressing Ecophobia”, The Journal of Environmental Education, 43 (1), pp. 37-54.

Taylor, Matthew A. (2012), "The Nature of Fear: Edgar Allan Poe and Posthuman Ecology", American Literature, 84 (2), pp. 353-79.

van Tine, Robin (1999), "Gaeaphobia: Ecophobia, Ecomania and 'Otherness' in the Late $20^{\text {th }}$ Century”, www.ecopsychology.org/journal/gatherings2/robin.htm (03.09.2019) 